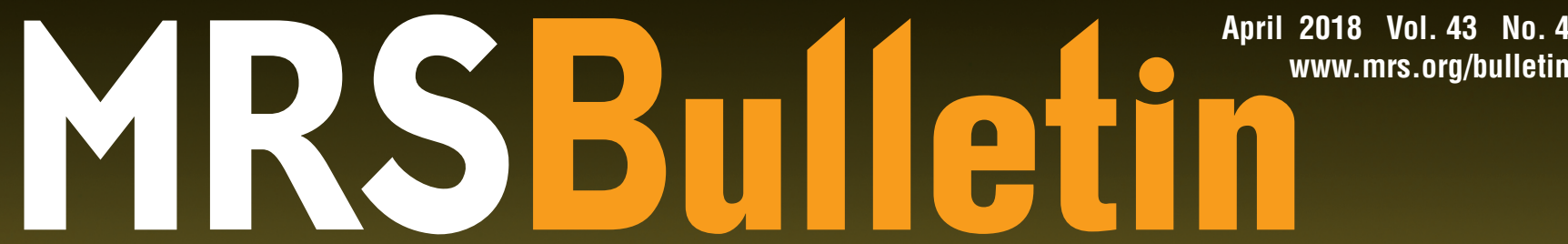

\title{
\begin{tabular}{l|l|l}
$M$ & $R$ & $S$ \\
Mdvancing materials. Improving the quality of life.
\end{tabular}
}

\section{Caloric effects in ferroic materials}






\section{CUSTOMIZED PRODUCTION ION IMPLANTERS}

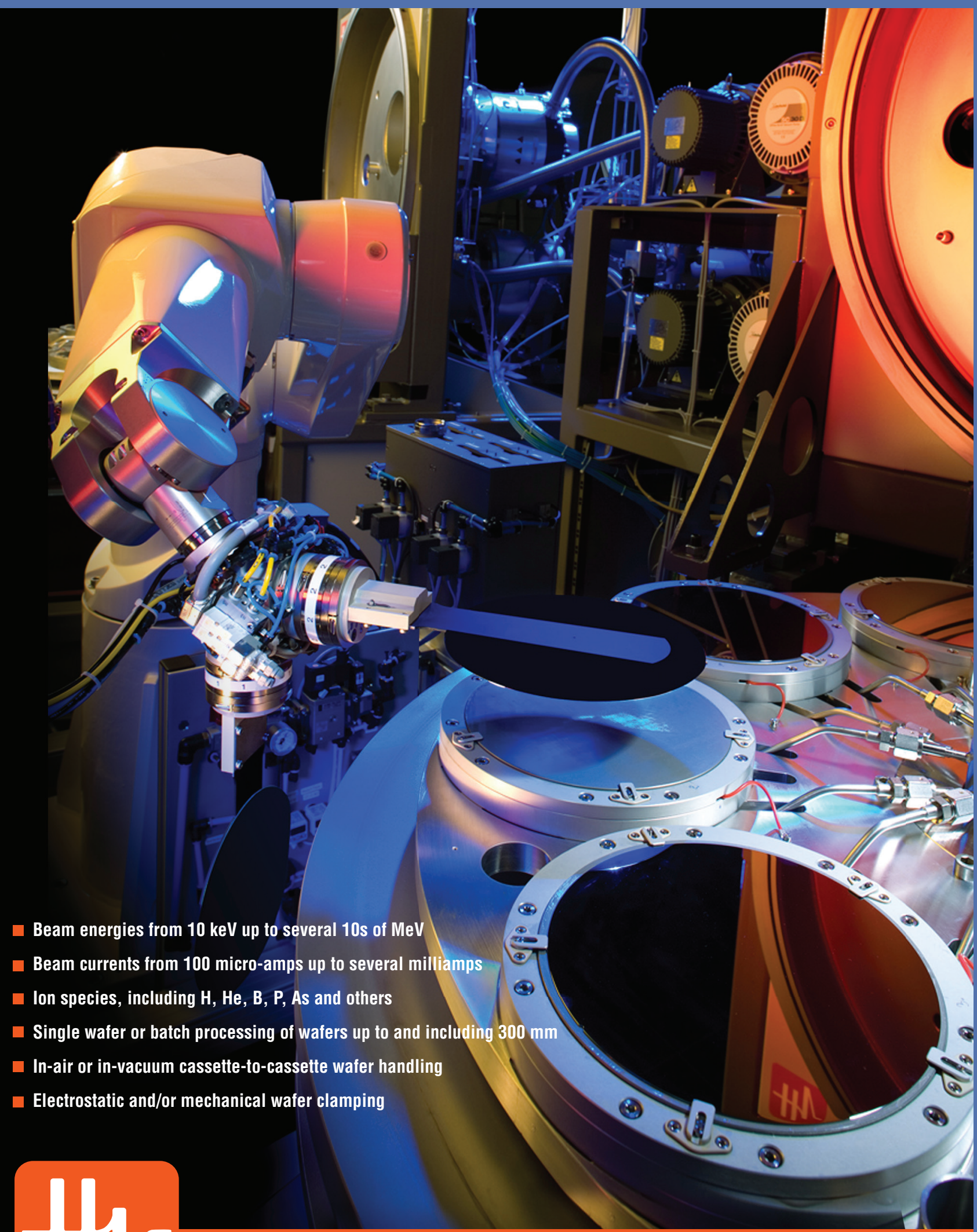

In-air or in-vacuum cassette-to-cassette wafer handling

Electrostatic and/or mechanical wafer clamping

\section{High Voltage Engineering}

High Voltage Engineering Europa B.V.

P.O. Box 99, 3800 AB Amersfoort, The Netherlands

Tel: 31334619741 • info@highvolteng.com

www.highvolteng.com 

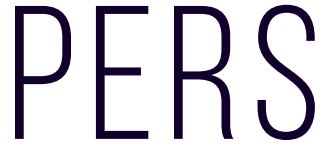

Abstract Submission Opens May 14, 2018

Abstract Submission Deadline June 14, 2018

\section{Fall Meeting registrations include MRS Membership January - December 2019}

\section{BROADER IMPACT}

BI01 Sustainable Development in Materials Science and Related Societal Aspects

BI02 The Future of Materials Science Academia-

Preparing for a Career in Higher Education

\section{BIOMATERIALS AND SOFT MATERIALS}

BM01 3D Printing of Passive and Active Medical Devices

BM02 Electronic and Coupled Transport in Biology

BM03 Multiscale Modeling of Soft Materials and Interfaces

BM04 Biomaterials for Regenerative Engineering

BM05 Advanced Manufacturing Technologies for Emulating Biological Tissues

BM06 Plasma Processing and Monitoring for Bioengineering and Biomedical Engineering

BM07 Bioelectronics-Fundamentals, Materials and Devices

BM08 Materials-to-Devices for Integrated Wearable SystemsEnergy Harvesting and Storage, Sensors/Actuators and Integration

BM09 Bioinspired Macromolecular Assembly and Inorganic CrystallizationFrom Tissue Scaffolds to Nanostructured Materials

\section{CHARACTERIZATION, MECHANICAL PROPERTIES AND} STRUCTURE-PROPERTY RELATIONSHIPS

CM01 Solid-State Chemistry of Inorganic Materials

CM02 Structure-Property Relations in Non-Crystalline Materials

CM03 In Situ/Operando Analysis of Electrochemical Materials and Interfaces

CM04 Ultrafast Optical Probes for Advanced Materials Characterization and Development

CM05 Fundamentals of Materials Property Changes Under Irradiation

\section{ELECTRONIC, PHOTONIC AND MAGNETIC MATERIALS}

EP01 New Materials and Applications of Piezoelectric, Pyroelectric and Ferroelectric Materials

EP02 Materials for Manipulating and Controlling Magnetic Skyrmions

EP03 Beyond-Graphene 2D Materials-

Synthesis, Properties and Device Applications

EP04 Novel Photonic and Plasmonic Materials Enabling New Functionalities

EP05 Excitons, Electrons and Ions in Organic Materials

EP06 Coherent Electronic Spin Dynamics in Materials and Devices

\section{MEETING CHAIRS}

Kristen H. Brosnan GE Global Research David LaVan National Institute of Standards and Technology Patrycja Paruch University of Geneva Joan M. Redwing The Pennsylvania State University Takao Someya The University of Tokyo

\section{www.mrs.org/fall2018}

\section{8 iMatSci Innovator Showcase}

CALL FOR EARLY-STAGE STARTUPS Submission Site Opens: June 1, 2018

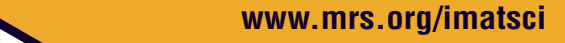

EP07 Tailored Disorder-Novel Materials for Advanced Optics and Photonics

EP08 Ultra-Wide-Bandgap Materials and Devices

EP09 Diamond Electronics, Sensors and BiotechnologyFundamentals to Applications

ENERGY-TRANSFER, STORAGE AND CONVERSION

ET01 Solid-State Batteries-Materials, Interfaces and Performance

ET02 Silicon for Photovoltaics

ET03 Application of Nanoscale Phenomena and Materials to Practical Electrochemical Energy Storage and Conversion

ET04 Perovskite Solar Cells-Challenges and Opportunities

ET05 Fundamental Aspects of Halide Perovskite (Opto)electronics and Beyond

ET06 Advanced Materials and Chemistries for High-Energy and Safe Rechargeable Batteries

ET07 Advanced Processing and Manufacturing for Energy Conversion, Storage and Harvesting Devices

ET08 Emerging Materials and Characterization for Selective Catalysis

ET09 Materials for Chalcogen Electrochemistry in Energy Conversion and Storage

ET10 Redox Active Materials and Flow Cells for Energy Applications

ET11 Emerging Materials and Device Concepts for Flexible, Low-Cost Photovoltaic Technologies

ET12 Harvesting Functional Defects in Energy Materials

ET13 Materials for Multifunctional Windows

ET14 Materials Science Facing Global Warming —Practical Solutions for Our Future

ET15 Scientific Basis for Nuclear Waste Management

\section{GENERAL INTEREST}

GI01 Machine Learning and Data-Driven Materials Development and Design GI02 Materials for Next-Generation Robotics

\section{NANOMATERIALS}

NM01 Carbon Nanotubes, Graphenes and Related Nanostructures

NM02 Nanometal-Synthesis, Properties and Applications

NM03 Nanowires and Related 1D NanostructuresNew Opportunities and Grand Challenges

NM04 Nanomaterials and Nanomanufacturing for Sustainability

\section{PROCESSING AND MANUFACTURING}

PM01 Architected Materials-

Synthesis, Characterization, Modeling and Optimal Design

PM02 Conductive Materials Reliability in Flexible Electronics

PM03 Hierarchical, Hybrid and Roll-to-Roll Manufacturing for Device Applications

PM04 High-Entropy Alloys

PM05 Electromagnetic Fields in Materials Synthesis-Far from Equilibrium Effects

PM06 Advances in Intermetallic-Based Alloys for Structural and Functional Applications

PM07 Plasma-Based Synthesis, Processing and Characterization of Novel Materials for Advanced Applications

THERMAL PROPERTIES AND THERMOELECTRIC MATERIALS

TP01 Caloric Materials for Highly Efficient Cooling Applications

TP02 Thermal Analysis-Materials, Measurements and Devices

TP03 Emerging Low-Temperature Thermal Energy Conversion Technologies

\section{R $\mathbf{S}$ MATERIALS RESEARCH SOCIETY Advancing materials. Improving the quality of life.}

506 Keystone Drive • Warrendale, PA 15086-7573

Tel 724.779.3003 • Fax 724.779.8313

info@mrs.org • www.mrs.org 


\section{MRSBulletin}
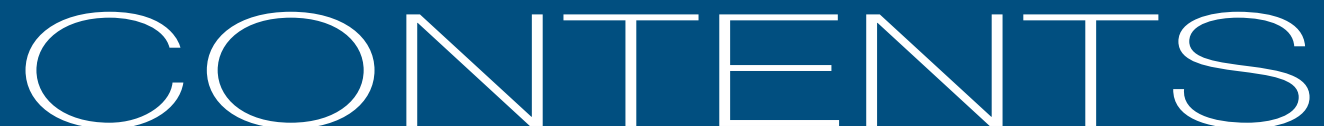

\section{CALORIC EFFECTS IN FERROIC MATERIALS}

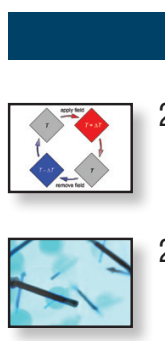

264 Caloric effects in ferroic materials

Sebastian Fähler and Vitalij K. Pecharsky, Guest Editors

269 Magnetocaloric materials for refrigeration near room temperature

Anja Waske, Markus E. Gruner, Tino Gottschall, and Oliver Gutfleisch

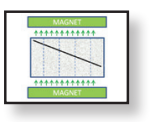

274 The evolution of magnetocaloric heat-pump devices

Carl Zimm, Andre Boeder, Bryant Mueller, Kyle Rule, and Steven L. Russek

280 High-performance elastocaloric materials for the engineering of bulk- and micro-cooling devices

Jan Frenzel, Gunther Eggeler, Eckhard Quandt,

Stefan Seelecke, and Manfred Kohl

285 Overcoming fatigue through compression for advanced elastocaloric cooling Huilong Hou, Jun Cui, Suxin Qian, David Catalini, Yunho Hwang, Reinhard Radermacher, and Ichiro Takeuchi

291 Electrocaloric effects in multilayer capacitors for cooling applications

Xavier Moya, Emmanuel Defay, Neil D. Mathur, and Sakyo Hirose

295 Multicaloric materials and effects Enric Stern-Taulats, Teresa Castán, Lluís Mañosa Antoni Planes, Neil D. Mathur, and Xavier Moya

\section{DEPARTMENTS}

\section{NEWS \& ANALYSIS}

253 Materials News

- Optical blasting of polycrystals manipulates grain boundaries Ahmad R. Kirmani

- Probing the buried interface between graphite layers YuHao Liu

- Flexoelectricity found in bone Vineet Venugopal

- Influence of grain boundaries on Li-ion conductivity characterized at atomic scale Tianyu Liu

- Health monitoring reaches new heights with human trials of ingestible sensor Rahim Munir

\section{Materials Education}

- The materials science and engineering undergraduate enrollment floodgates are open R. Allen Kimel and Susan B. Sinnott

\section{Science Policy}

- US National Academies report on integrity in science Jennifer A. Nekuda Malik

- EU aviation and shipping face big challenges in reducing environmental impact 


\section{SOCIETY NEWS}

\section{0 - MRS Communications Abstracts \\ 308 - Profiles \\ Sophie Robinson, Environmentalist \\ and Film Producer \\ Humaira Taz}

\section{DIVERSITY IN MS\&E}

- Queer identities in materials science and engineering

Keith J. Bowman

Feature Editor: Lynnette D. Madsen



\section{ON THE COVER}

Caloric effects in ferroic materials. The worldwide energy usage for cooling by refrigerators and air conditioners is substantial. This issue of MRS Bulletin introduces ongoing developments in ferroiccaloric materials and their applications to cooling devices, including those beyond refrigeration such as magnetocaloric materials being explored for hyperthermia therapy. The cover shows a color-coded infrared thermograph obtained during elastocaloric cooling. The image documents temperature changes in the elastocaloric NiTi ribbon subjected to mechanical cycling between two $\mathrm{Cu}$ blocks. A significant temperature difference between the two blocks is established after a few elastocaloric cycles. Image courtesy of Marvin Schmidt. See the technical theme that begins on p. 264.

\section{FEATURES}

\section{Book Reviews}

- The Development of Catalysis: A History of Key Processes and Personas in Catalytic Science and Technology Adriano Zecchina and Salvatore Califano Reviewed by Karen Swider Lyons

- Materials for a Healthy, Ecological and Sustainable Built Environment: Principles for Evaluation Emina Kristina Petrović, Brenda Vale, and Maibritt Pedersen Zari Reviewed by Miriam Sánchez Pozos

- Advanced Transmission Electron Microscopy: Imaging and Diffraction in Nanoscience Jian Min Zuo and John C.H. Spence Reviewed by Wanfeng Li

312 Image Gallery Look Again

\section{CAREER CENTRAL}

\section{ADVERTISERS IN THIS ISSUE}

American Elements High Voltage Engineering

National Electrostatics Corp

Rigaku Corporation.
Page No.

Outside back cove .. Inside front cover 268 .290 


\section{$\mathrm{M}|\mathrm{R}| \mathrm{S}$}

MATERIALS RESEARCH SOCIETY ${ }^{\oplus}$

Advancing materials. Improving the quality of life.
EDITORIAL OFFICE 506 Keystone Drive, Warrendale, PA 15086-7573 USA Bulletin@mrs.org tel 724.779.2747 fax 724.779.8313 www.mrs.org

\section{About the Materials Research Society}

The Materials Research Society (MRS), a not-for-profit scientific association founded in 1973 and headquartered in Warrendale, Pennsylvania, USA, promotes interdisciplinary materials research. Today, MRS is a growing, vibrant, member-driven organization of over 16,000 materials researchers spanning over 80 countries, from academia, industry, and government, and a recognized leader in the advancement of interdisciplinary materials research.

The Society's interdisciplinary approach differs from that of single-discipline professional societies because it promotes information exchange across many scientific and technical fields touching materials development. MRS conducts three major international annual meetings and also sponsors numerous single-topic scientific meetings. The Society recognizes professional and technical excellence and fosters technical interaction through University Chapters. In the international arena, MRS implements bilateral projects with partner organizations to benefit the worldwide materials community. The Materials Research Society Foundation helps the Society advance its mission by supporting various projects and initiatives.

2018 MRS BOARD OF DIRECTORS

President Sean J. Hearne, Sandia National Laboratories, USA

Immediate Past President Susan Trolier-McKinstry,

The Pennsylvania State University, USA

Vice President and President-Elect Michael R. Fitzsimmons,

Oak Ridge National Laboratory and The University of Tennessee, USA

Secretary Eric A. Stach, University of Pennsylvania, USA

Treasurer David J. Parrillo, The Dow Chemical Company, USA

Executive Director Todd M. Osman, Materials Research Society, USA

Griselda Bonilla, IBM T.J. Watson Research Center, USA

Li-Chyong Chen, National Taiwan University, Taiwan

Matt Copel, IBM T.J. Watson Research Center, USA

Paul S. Drzaic, Apple, Inc., USA

Dawnielle Farrar-Gaines, Johns Hopkins University, USA

Yury Gogotsi, Drexel University, USA

Claudia Gutiérrez-Wing, Instituto Nacional de Investigaciones Nucleares, Mexico

Young-Chang Joo, Seoul National University, South Korea

Lincoln J. Lauhon, Northwestern University, USA

Lincoln J. Lauhon, Northwestern University,

Christopher A. Schuh, Massachusetts Institute of Technology, USA

Rachel A. Segalman, University of California, Santa Barbara, USA

Magaly Spector, The University of Texas at Dallas, USA

Molly M. Stevens, Imperial College London, UK

Ehrenfried Zschech, Fraunhofer Institute for Ceramic Technologies and Systems, Germany

\section{MRS OPERATING COMMITTEE CHAIRS}

Academic Affairs Bruce M. Clemens, Stanford University, USA Awards Albert Polman, FOM Institute AMOLF, The Netherlands Government Affairs David P. Norton, University of Florida, USA Meetings Terry Aselage, Sandia National Laboratories, USA Member Engagement Sossina M. Haile, Northwestern University, USA Public Outreach Elizabeth Kupp, The Pennsylvania State University, USA Publications Shefford P. Baker, Cornell University, USA

\section{MRS HEADQUARTERS}

Todd M. Osman, Executive Directo

J. Ardie Dillen, Director of Finance and Administration

Damon Dozier, Director of Government Affairs

Patricia Hastings, Director of Meetings Activities

Eileen M. Kiley, Director of Communications
Editor

Gopal R. Rao, rao@mrs.org

Managing Editor

Lori A. Wilson, Iwilson@mrs.org

News Editor

Judy Meiksin, meiksin@mrs.org

Technical Editor

Lisa C. Oldham, oldham@mrs.org

Editorial Assistants

Michelle S. Raley, raley@mrs.org

Mary Wilmoth

Associate Technical Editor

Tim Palucka

Production/Design

Michael P. Moran, Rebecca Tokarczyk

Felicia Turano, and TNQ

Associate Production Editor

Katie Wurtzel

Principal Development Editor

Elizabeth L. Fleischer

Director of Communications

Eileen M. Kiley
Guest Editors

Sebastian Fähler and Vitalij K. Pecharsky

Special Consultant

Angelika Veziridis

Energy Quarterly

Andrea Ambrosini (Chair),

Monika Backhaus, Kristen Brown,

David Cahen, Russell R. Chianelli,

George Crabtree, Elizabeth A. Kócs,

Shirley Meng, Sabrina Sartori,

Anke Weidenkaff, M. Stanley

Whittingham, and Steve M. Yalisove

Advertising/Sponsorship

Mary E. Kaufold, kaufold@mrs.org

Donna L. Watterson, watterson@mrs.org

Member Subscriptions

Michelle Judt, judt@mrs.org

Non-Member Subscriptions

subscriptions_newyork@cambridge.org

\section{EDITORIAL BOARD}

Fiona C. Meldrum (Chair), University of Leeds, UK

Ilke Arslan, Pacific Northwest National Laboratory, USA

V.S. Arunachalam, Center for Study of Science, Technology \& Policy, India

N. (Balu) Balasubramaniam, Bangalore, India (retired)

Christopher J. Bettinger, Carnegie Mellon University, USA

Tommie Kelley, 3M, USA

Igor Lubomirsky, Weizmann Institute, Israe

Amit Misra, University of Michigan, USA

Steven C. Moss, The Aerospace Corporation, USA (retired)

Julie A. Nucci, Cornell University, USA

Linda J. Olafsen, Baylor University, USA

Boaz Pokroy, Technion-Israel Institute of Technology, Israel

Zhiwei Shan, Xi'an Jiaotong University and Hysitron, China

James W. Stasiak, HP Inc., USA

Carol Trager-Cowan, University of Strathclyde, UK

Eric Werwa, Washington, DC, USA

M. Stanley Whittingham, Binghamton University, The State University of New York, USA

Steve M. Yalisove, University of Michigan, USA

\section{VOLUME ORGANIZERS}

2018 Karsten Albe, Technische Universität Darmstadt, Germany Hiroshi Funakubo, Tokyo Institute of Technology, Japan Michael Hickner, The Pennsylvania State University, USA Bethanie Stadler, University of Minnesota, USA

2019 Craig B. Arnold, Princeton University, USA

Claus Daniel, Oak Ridge National Laboratory and The University of Tennessee, Knoxville, USA

Seung Min Han, Korea Advanced Institute of Science and Technology, South Korea Gabriel Montaño, Los Alamos National Laboratory/Northern Arizona University, USA

MRS Bulletin (ISSN: 0883-7694, print; ISSN 1938-1425, online) is published monthly by the Materials Research Society, 506 Keystone Drive, Warrendale, PA 15086-7573. @ 2018 Materials Research Society. Permission required to reproduce content. Periodical postage paid at New York, NY, and at additional mailing offices. POSTMASTER: Send address changes to MRS Bulletin in care of the Journals Department, Cambridge University Press, 100 Brook Hill Drive, West Nyack, NY 10994-2113, USA. Printed in the U.S.A.

Membership in MRS is $\$ 130$ annually for regular members, $\$ 32$ for students, and includes an electronic subscription to MRS Bulletin. Print subscriptions are available to MRS members for an additional $\$ 25$. Individual member subscriptions are for personal use only. Non-member subscription rates are $\$ 560$ (USD) for one calendar year (12 issues). Requests from subscribers for missing journal issues will be honored without charge only if received within six months of the issue's actual date of publication.

MRS Bulletin is included in Current Contents $\otimes /$ Engineering, Computing, and Technology; Current Contents ${ }^{\oplus / P h y s i c a l, ~ C h e m i c a l, ~ a n d ~ E a r t h ~ S c i e n c e s, ~ t h e ~ S c i S e a r c h ~}{ }^{\circledast}$ online database, Research Alert ${ }^{\oplus}$, Science Citation Index ${ }^{\oplus}$, and the Materials Science Citation Index ${ }^{\top M}$. Back volumes of MRS Bulletin are available on microfiche through University Microfilms Inc. 300 North Zeeb Road, Ann Arbor, MI 48106, USA

Authors of each technical article appearing in MRS Bulletin are solely responsible for all content in their article(s), including accuracy of the facts, statements, and citing resources. Facts and opinions are solely the personal statements of the respective authors and do not necessarily represent the views of the editors, the Materials Research Society, or Cambridge University Press

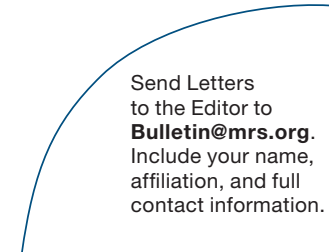

